\title{
PHYTOCHEMICAL SCREENING, TOTAL FLAVONOID, ANTIOXIDANT ACTIVITY, AND TOXICITY OF ETHANOL EXTRACT Cleome gynandra L. HERB
}

\author{
${ }^{1 * A g u s t i n u s ~ W i d o d o, ~}{ }^{1}$ Ritha Pratiwi \\ ${ }^{I}$ Department of Pharmacy, Faculty of Mathematics and Natural Sciences, Tadulako University, Palu, \\ Indonesia \\ Jl. Soekarno-Hatta KM.9,Palu, Sulawesi Tengah 94148 \\ * Corresponding author: widodoagustinus.untad@gmail.com \\ Co-author 1, email: rithanajmuddin5@gmail.com
}

\begin{abstract}
Cleome gynandra L. is one of the plants that the people of Palu, Central Sulawesi use as food ingredients. This plant is empirically used in traditional medicine. This study aims to determine phytochemical constituents, total flavonoid, antioxidant activity, and toxicity of 96\% ethanol extract of $C$. gynandra herb. C. gynandra herb extract was obtained by maceration. Phytochemical screening of the ethanol extract was carried out qualitatively according to the standard methods. Determination of total flavonoid using $\mathrm{AlCl}_{3}$ then determined by Spectrophotometric UV-Vis. Antioxidant activity using the DPPH method and determined $I C_{50}$ value. Toxicity test was assessed using shrimp lethality as an indicator of toxicity. Phytochemical screening showed $96 \%$ ethanol extract containing alkaloid compounds, flavonoids, saponins, steroids, and tannins. Total flavonoid of the $96 \%$ ethanol extract was 4,778 $\pm 0,522 \mathrm{mg} Q E / g$ extract. Antioxidant activity $\left(I C_{50}\right)$ of the ethanol $96 \%$ extract was $189,455 \mu \mathrm{g} / \mathrm{ml}$. Lethal concentration $50 \%$ of the $96 \%$ ethanol extract was $472,648 \mathrm{mg} / \mathrm{L}$ (toxic). The results of this study indicate that $96 \%$ ethanol extract of $C$. gynandra herb has antioxidant activity and has the potential to be further tested as an anticancer activity.
\end{abstract}

Keywords: Cleome gynandra L., total flavonoid, antioxidan, toxicity

\section{INTRODUCTION}

Free radicals are reactive molecules produced from various processes in the body, such as metabolism, cell respiration, and inflammatory reactions. Free radicals not only come from the body, but can also be produced from environmental pollution, excessive exposure to ultraviolet light, gamma ray radiation, X-ray radiation, and cigarette smoke. At high concentrations, free radicals can oxidize cell components such as nucleic acids, proteins, fats, and DNA, so that they can initiate the onset of various diseases such as hypertension, atherosclerosis, neurological disorders, diabetes, asthma, aging and even cancer [1-2]. 
Antioxidants are compounds that can counteract and prevent damage caused by free radical compounds [3]. The source of antioxidants can be synthetic antioxidants and natural antioxidants. Synthetic antioxidants such as synthetic antioxidants such as Butylated hydroxyanisole (BHA) and Butylated hydroxytoluene (BHT) are limited because the results of animal studies indicate that these compounds can cause liver and kidney dysfunction, allergic reactions, and are carcinogenic. Therefore, now more and more research is conducted on natural ingredients that have antioxidant activity and are not toxic [4-5].

Flavonoids are the most common phenolic compounds, because they are widely distributed in plant tissues, and are responsible for giving color to plants. Flavonoids have a 15-carbon frame consisting of two substituted benzene rings connected by a three-carbon aliphatic chain [6]. Phenolic compounds can provide protection as antioxidants because phenolic compounds can react with reactive oxygen species (ROS) and eliminate their radical activity so that they are no longer harmful to human body cells [7]. These phenolic compounds can prevent heart disease, reduce inflammation, reduce the incidence of cancer and diabetes, and reduce the level of mutagenesis in human cells. The protection gained from consuming plant products such as fruits, vegetables and nuts is mostly related to the presence of phenolic compounds in these plants [8].

Cleome gynandra L. is known as Bavoa (Kaili tribe) by most of the people of Central Sulawesi, especially the Palu, Donggala, and Sigi areas using it as food (vegetables). This plant is known to contain beta carotene, vitamin C, and levels of calcium, magnesium, and iron. C. gynandra in Africa, empirically used to induce labor, increase lactation, increase blood, reduce migraines, vomiting, diphtheria, vertigo, headache, pneumonia, ear infections, abdominal pain, eyewash, and consumption of boys after circumcision [9]. This study aims to determine the antioxidant activity and toxicity of the ethanol extract of $C$. gynandra herb so that scientific information is obtained for the development of this plant in the field of health, especially pharmacy.

\section{MATERIAL AND METHOD}

\section{Materials}

C. gynandra herb; 96\% Ethanol; Methanol p.a; Quercetin (Sigma); DPPH (2,2Diphenyl-1-picrylhydrazyl) (Sigma), 10\% Aluminum chloride; Potassium acetate; distilled water; sea water; and shrimp eggs (Artemia salina). 


\section{Instrumentation}

UV-Vis Spectrophotometer (Cecil CE 7410); rotary evaporator (Eyela); micropipette; analytical balance; water bath, aerator; hatching lights; vial; and laboratory glassware.

\section{Procedure}

\section{Plant Materials and Extraction Preparation}

C. gynandra herb were obtained from a cultivated crop in Sigi, Central Sulawesi, Indonesia. This plant was identified by the Department of Biology, Faculty of Pharmacy, Airlangga University under the voucher number voucher number 80/UN28.1.28/BIO/2018. Simplicia powder of $C$. gynandra herb was macerated using $96 \%$ ethanol with a ratio (1:10 w/v) for $3 \times 24$ hours to obtain the filtrate. The filtrate is then concentrated by a rotary vacuum evaporator at $50^{\circ} \mathrm{C}$ and a water bath to get a dried extract.

\section{Phytochemical Screening}

Secondary metabolite phytochemical screening uses the standard method for qualitative testing of the content of alkaloids, flavonoids, saponins, steroids, and tannins [10-11].

\section{Total Flavonoid Content}

Total flavonoid content was determined using Aluminum chloride assay [12]. $10 \mathrm{mg}$ of the extract was dissolved in $10 \mathrm{ml}$ of $96 \%$ ethanol to obtain a concentration of $1000 \mathrm{ppm}$, as much as $0.5 \mathrm{ml}$ of the test sample was added $1.5 \mathrm{~mL}$ of $96 \%$ ethanol, $0.1 \mathrm{ml}$ of Aluminum chloride $10 \%, 0.1 \mathrm{ml}$ of $1 \mathrm{M}$ Potassium acetate, and $2.8 \mathrm{ml}$ of distilled water. Incubated for 30 minutes, absorbance was measured using a UV-Vis spectrophotometer at maximum wavelength. Total flavonoid content was expressed as milligrams of quercetin equivalent per gram of dry extract (mg QE/g DE) via a quercetin calibration curve with a linearity range of $5-40 \mu \mathrm{g} / \mathrm{mL}$ and $\mathrm{R}^{2}=0.9677$ (Figure 1).

\section{Antioxidant Activity}

The antioxidant activity of the extract was measured based on the reducing activity of free radicals 2,2-Diphenyl-1-picrylhydrazyl (DPPH). The extract was dissolved in methanol at five different concentration variations $(100-300 \mu \mathrm{g} / \mathrm{mL}) .1 \mathrm{~mL}$ extract was mixed with 1 $\mathrm{mL} 0.1 \mathrm{mM}$ DPPH, incubated for 30 minutes at room temperature and dark area, then the 
absorbance of the solution was measured using a UV-Vis spectrophotometer at maximum wavelength. Pure methanol is used as a blank solution and DPPH is used as a control solution [13]. The percentage of inhibition of DPPH radical from each sample solution concentration was calculated by the formula:

$$
\text { Inhibition }(\%)=[(\text { Abs. control }- \text { Abs. sample }) / \text { Abs. control })] \times 100
$$

The 50\% inhibitory concentration $\left(\mathrm{IC}_{50}\right)$ was calculated by plotting the percentage of inhibition to the sample concentration (Figure 2). Quercetin is used as a standard (Figure 3).

\section{Toxicity Test}

A. salina eggs are placed in a container filled with filtered sea water. The eggs, continue to be given light for 48 hours until the hatch is perfect. Ethanol extract was dissolved in sea water to obtain concentrations of 50, 100, 200, 500, and $1000 \mathrm{ppm}$. The extract solution was then put into a vial and added 10 shrimp larvae, left at room temperature and the number of live larvae counted after 24 hours [14]. The test was carried out using three replications. The lethal concentration of $50 \%\left(\mathrm{LC}_{50}\right)$ was determined using a correlation curve between the extract concentration of $\log 10(\mathrm{x}$-axis) and the probit value (yaxis) (Figure 4).

\section{RESULTS AND DISCUSSION}

\section{Phytochemical Screening}

Phytochemical screening showed $C$. gynandra herb containing alkaloid compounds, flavonoids, saponins, steroids, and tannins (Table 1). These compounds are known to show medical and physiological activity. Alkaloids are reported to have antispasmodic and antibacterial activity [15]. Flavonoids are known to have antiviral activity [16-17], antioxidants, antiarterosclerosis, anti-inflammatory, prevent neurodegenerative diseases, and anticancer [18-20]. Saponins are known to have anti-inflammatory activity [21]. Steroids are reported to have antibacterial activity and are associated with sex hormones [22-23]. Tannins are reported to have antifungal, antibacterial, and antiviral activity [24].

\section{Total Flavonoid Content}

The results of the determination of total flavonoid of $96 \%$ ethanol extract of $C$. gynandra herb obtained levels of $4.778 \pm 0.522 \mathrm{mg} \mathrm{QE} / \mathrm{g}$ extract (Table 2). Flavonoids are natural antioxidant compounds, which have solubility in polar solvents such as water, 
methanol, and ethanol. Flavonoid glycosides are easily soluble in water, methanol, and ethanol, whereas flavonoids of aglycones only dissolve in methanol and ethanol. This study uses $96 \%$ ethanol solvent. Based on the type of solvent used, flavonoid compounds extracted are flavonoid glycosides and aglycone flavonoids [25-26]. Research conducted by Do et al. [27] reported variations in concentration and type of solvents affecting total flavonoids and antioxidant activity. In the future it is necessary to do research on variations in concentration or type of solvent, to determine its effect on the total flavonoids of $C$. gynandra herb.

\section{Antioxidant Activity}

Antioxidant activity $\left(\mathrm{IC}_{50}\right)$ of $96 \%$ ethanol extract of $C$. gynandra herb was lower than quercetin. The antioxidant activity of $C$. gynandra herb was about 7 times lower than quercetin (Table 2). Research conducted by Ira, S. et al. [28] reported that extract from each part of the plant showed different antioxidant activities. The samples used in this study are aerial parts of the plant (stems, leaves, flowers, and fruit), so that it is necessary to study the antioxidant activity of each plant organ, including the roots, to determine the potential of each part of the C. gynandra.

\section{Toxicity Test}

Lethal concentration $50 \%\left(\mathrm{LC}_{50}\right)$ of $96 \%$ ethanol extract of $C$. gynandra herb is $472,648 \mathrm{mg} / \mathrm{L}$ (Table 2). $\mathrm{LC}_{50}$ value $<1000 \mathrm{mg} / \mathrm{L}$, indicating that $96 \%$ ethanol extract of $C$. gynandra herb is toxic to A. salina larvae [29]. These results indicate that $96 \%$ ethanol extract of $C$. gynandra herb has the potential to be further tested as an anticancer activity. The activity was suspected due to the content of alkaloid [30] and flavonoid compounds $[18,20]$ in the extract of $C$. gynandra herb.

\section{CONCLUSION}

C. gynandra has antioxidant activity and has the potential as an anticancer, so further testing is needed to develop this plant, especially in herbal medicine. 


\section{REFERENCES}

[1] Leong, L.P. and Shui, G., 2002. An investigation of antioxidant capacity of fruits in Singapore markets. Food chemistry, 76(1), pp.69-75. https://doi.org/10.1016/S0308$\underline{8146(01) 00251-5}$

[2] Liochev, S.I., 2013. Reactive oxygen species and the free radical theory of aging. Free Radical Biology and Medicine, 60, pp.1-4.

https://doi.org/10.1016/j.freeradbiomed.2013.02.011

[3] Pham-Huy, L.A., He, H. and Pham-Huy, C., 2008. Free radicals, antioxidants in disease and health. International journal of biomedical science: IJBS, 4(2), p.89.

[4] Miyake, T. and Shibamoto, T., 1997. Antioxidative activities of natural compounds found in plants. Journal of agricultural and food chemistry, 45(5), pp.1819-1822. https://doi.org/10.1021/jf960620c

[5] Gupta, V.K. and Sharma, S.K., 2006. Plants as natural antioxidants. Natural Product Radiance, 5(4), 2006, pp.326-334

[6] Amić, D., Davidović-Amić, D., Bešlo, D. and Trinajstić, N., 2003. Structure-radical scavenging activity relationships of flavonoids. Croatica chemica acta, 76(1), pp.5561.

[7] Sochor, J., Zitka, O., Skutkova, H., Pavlik, D., Babula, P., Krska, B., Horna, A., Adam, V., Provaznik, I. and Kizek, R., 2010. Content of phenolic compounds and antioxidant capacity in fruits of apricot genotypes. Molecules, 15(9), pp.6285-6305.

$\underline{10.3390 / \text { molecules } 15096285}$

[8] Khoddami, A., Wilkes, M.A. and Roberts, T.H., 2013. Techniques for analysis of plant phenolic compounds. Molecules, 18(2), pp.2328-2375. 10.3390/molecules 18022328

[9] Silué, D., 2009. Spider plant: An indigenous species with many uses. The world vegetable centre, AVRDC publication, pp.09-719.

[10] Harborne, J.B., 1984. Phytochemical methods. Chapman and Hall, New York, 3, pp.37-201.

[11] Farnsworth, N.R., 1966. Biological and phytochemical screening of plants. Journal of pharmaceutical sciences, 55(3), pp.225-276. https://doi.org/10.1002/jps.2600550302

[12] Chang, C.C., Yang, M.H., Wen, H.M. and Chern, J.C., 2002. Estimation of total flavonoid content in propolis by two complementary colorimetric methods. Journal of food and drug analysis, 10(3), pp. 178-182.

[13] Brand-Williams, W., Cuvelier, M.E. and Berset, C.L.W.T., 1995. Use of a free radical method to evaluate antioxidant activity. LWT-Food science and Technology, 28(1), pp.25-30. 10.1016/S0023-6438(95)80008-5

[14] Meyer, B.N., Ferrigni, N.R., Putnam, J.E., Jacobsen, L.B., Nichols, D.E. and McLaughlin, J.L., 1982. Brine shrimp: a convenient general bioassay for active plant constituents. Planta med, 45(5), pp.31-34. 10.1055/s-2007-971236

[15] Kaur, R. A. J. B. I. R., \& Arora, S. A. R. O. J., 2015. Alkaloids-important therapeutic secondary metabolites of plant origin. Journal of Critical Reviews, 2(3), pp.1-8.

[16] Wei, F., Ma, S.C., Ma, L.Y., But, P.P.H., Lin, R.C. and Khan, I.A., 2004. Antiviral Flavonoids from the Seeds of Aesculus c hinensis. Journal of natural Products, 67(4), pp.650-653. https://doi.org/10.1021/np030470h

[17] Widodo, A., Widiyanti, P. and Prajogo, B., 2018. Antiviral activity of Justicia gendarussa Burm. f. leaves against HIV-infected MT-4 cells. African journal of infectious diseases, 12(1S), pp.36-43. 10.2101/Ajid.12v1S.4 
[18] Panche, A. N., Diwan, A. D., \& Chandra, S. R., 2016. Flavonoids: an overview. Journal of Nutritional Science, 5(47), pp.1-15. 10.1017/jns.2016.41

[19] Céspedes, C.L., 2013. Antioxidant and biocidal activities from natural sources: An overview. Cabi Publishing: Wallingford, Oxfordshire, UK, pp.1-10.

[20] Patel, J. M. (2008). A review of potential health benefits of flavonoids. Lethbridge Undergraduate Research Journal, 3(2), pp.1-5.

[21] Just, M. J., Recio, M. C., Giner, R. M., Cuéllar, M. J., Máñez, S., Bilia, A. R., \& Ríos, J. L., 1998. Anti-inflammatory activity of unusual lupane saponins from Bupleurum fruticescens. Planta medica, 64(05), pp.404-407. 10.1055/s-2006-957469

[22] Epand, R. F., Savage, P. B., \& Epand, R. M., 2007. Bacterial lipid composition and the antimicrobial efficacy of cationic steroid compounds (Ceragenins). Biochimica et Biophysica Acta (BBA)-Biomembranes, 1768(10), pp.2500-2509.

10.1016/j.bbamem.2007.05.023

[23] Chauhan, N. S., Sharma, V., Dixit, V. K., \& Thakur, M., 2014. A review on plants used for improvement of sexual performance and virility. BioMed research international, 24, pp.1-19. 10.1155/2014/868062

[24] Chung, K. T., Wong, T. Y., Wei, C. I., Huang, Y. W., \& Lin, Y., 1998. Tannins and human health: a review. Critical reviews in food science and nutrition, 38(6), pp.421464. 10.1080/10408699891274273

[25] Chebil, L., Humeau, C., Anthoni, J., Dehez, F., Engasser, J. M., \& Ghoul, M., 2007. Solubility of flavonoids in organic solvents. Journal of Chemical \& Engineering Data, 52(5), pp.1552-1556. https://doi.org/10.1021/je7001094

[26] Ferreira, O. and Pinho, S.P., 2012. Solubility of flavonoids in pure solvents. Industrial \& Engineering Chemistry Research, 51(18), pp.6586-6590. https://doi.org/10.1021/ie300211e

[27] Do, Q.D., Angkawijaya, A.E., Tran-Nguyen, P.L., Huynh, L.H., Soetaredjo, F.E., Ismadji, S. and Ju, Y.H., 2014. Effect of extraction solvent on total phenol content, total flavonoid content, and antioxidant activity of Limnophila aromatica. Journal of food and drug analysis, 22(3), pp.296-302. 10.1016/j.jfda.2013.11.001

[28] Ira, S., Manisha, M., Singh, G.P. and Anirudha, R., 2014. Quantitative estimation of phenolic and flavonoid content and antioxidant activity of various extracts of different parts of Plumbago zeylanica Linn. Int. J. Drug Dev. \& Res, 6(2), pp.136-140.

[29] Solis, P.N., Wright, C.W., Anderson, M.M., Gupta, M.P. and Phillipson, J.D., 1993. A microwell cytotoxicity assay using Artemia salina (brine shrimp). Planta medica, 59(3), pp.250-252. https://doi.org/10.1055/s-2006-959661

[30] Lu, J.J., Bao, J.L., Chen, X.P., Huang, M. and Wang, Y.T., 2012. Alkaloids isolated from natural herbs as the anticancer agents. Evidence-Based Complementary and Alternative Medicine, 2012. http://dx.doi.org/10.1155/2012/485042 


\section{J. Islamic Pharm. $2018 . \quad 3(2) .41-50$}

Table 1. Phytochemical screening of $96 \%$ ethanol extract of $C$. gynandra herb

\begin{tabular}{cc}
\hline Phytocemicals & Test Results \\
\hline Alkaloids & + \\
Flavonoids & + \\
Saponins & + \\
Steroids & + \\
Tannins & + \\
\hline
\end{tabular}

Table 2. Antioxidant activity, total flavonoid, and toxicity of $96 \%$ ethanol extract of $C$. gynandra herb

\begin{tabular}{cccc}
\hline Sample & $\begin{array}{c}\text { Antioxidant } \\
\mathbf{I C}_{\mathbf{5 0}}(\mathbf{\%})\end{array}$ & $\begin{array}{c}\text { Total Flavonoid } \\
(\mathbf{m g} \text { QE/g ekstrak) }\end{array}$ & $\begin{array}{c}\text { Toxicity } \\
\mathbf{L C}_{\mathbf{5 0}}(\mathbf{m g} / \mathbf{L})\end{array}$ \\
\hline $\begin{array}{c}\text { C. } \text { gynandra } \text { herb extract } \\
\text { Quercetin }\end{array}$ & 189,455 & $4,778 \pm 0,522$ & 472,648 \\
\hline
\end{tabular}

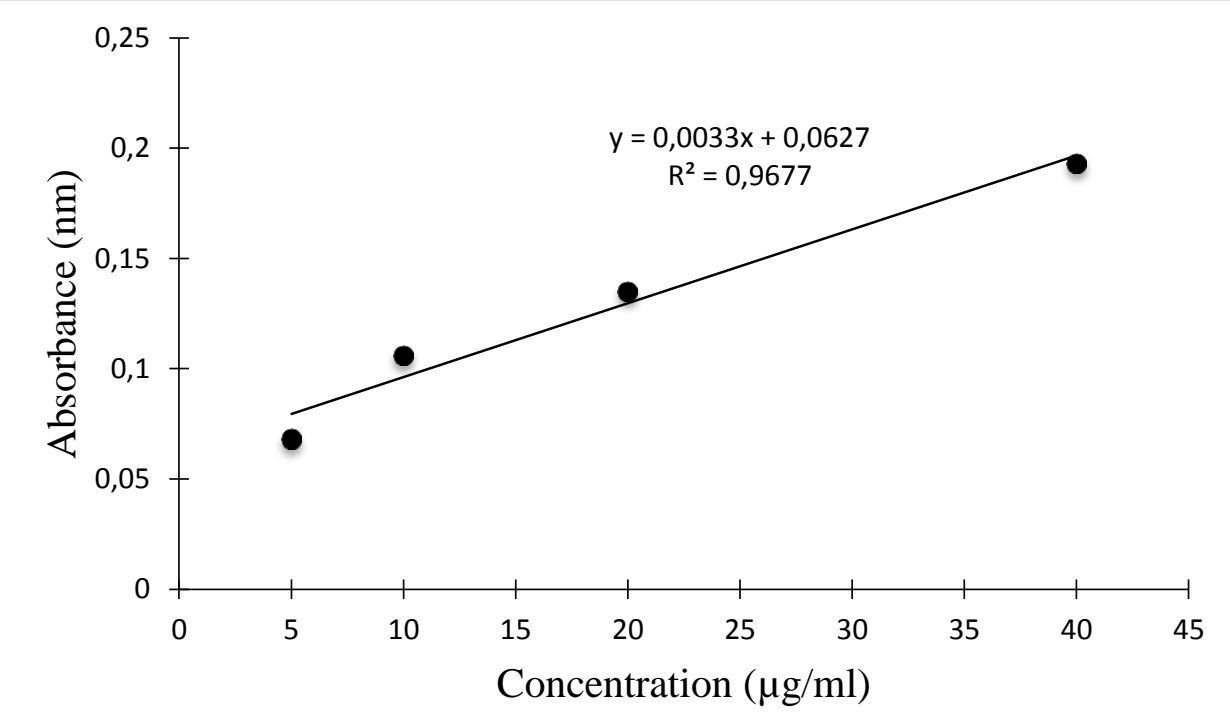

Figure 1. Calibration curve for standard quercetin 


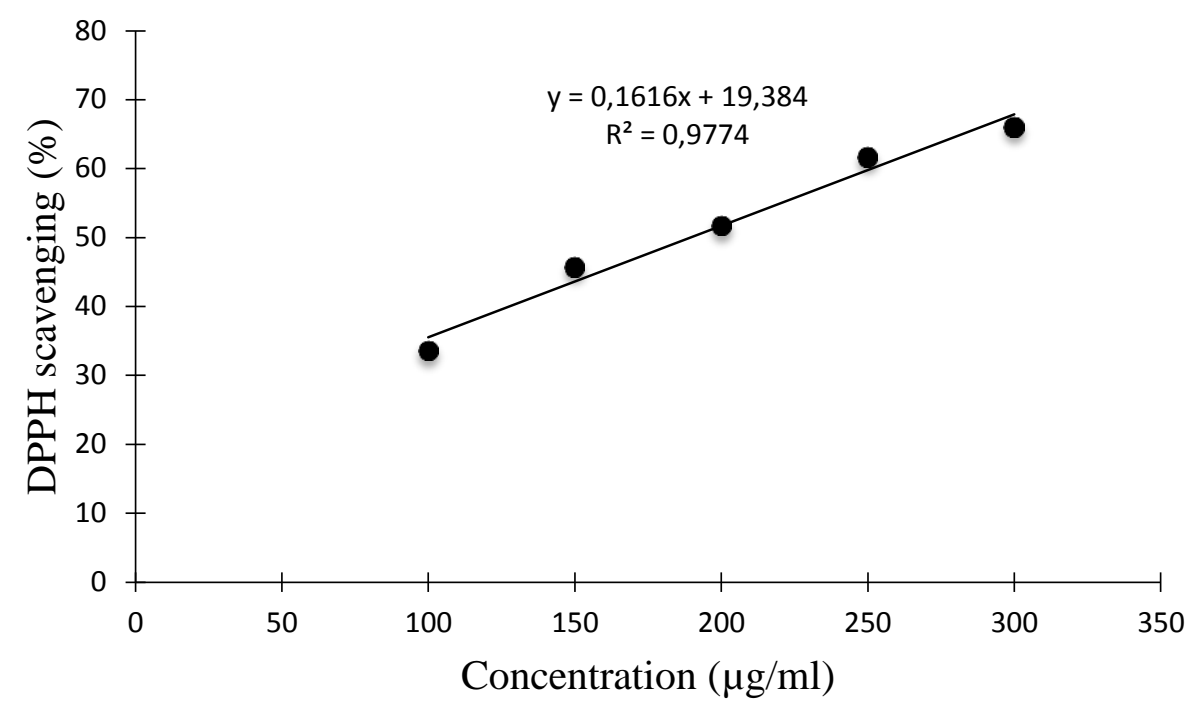

Figure 2. The DPPH free radical scavenging activity (\%) of $96 \%$ ethanol extract of $C$. gynandra herb

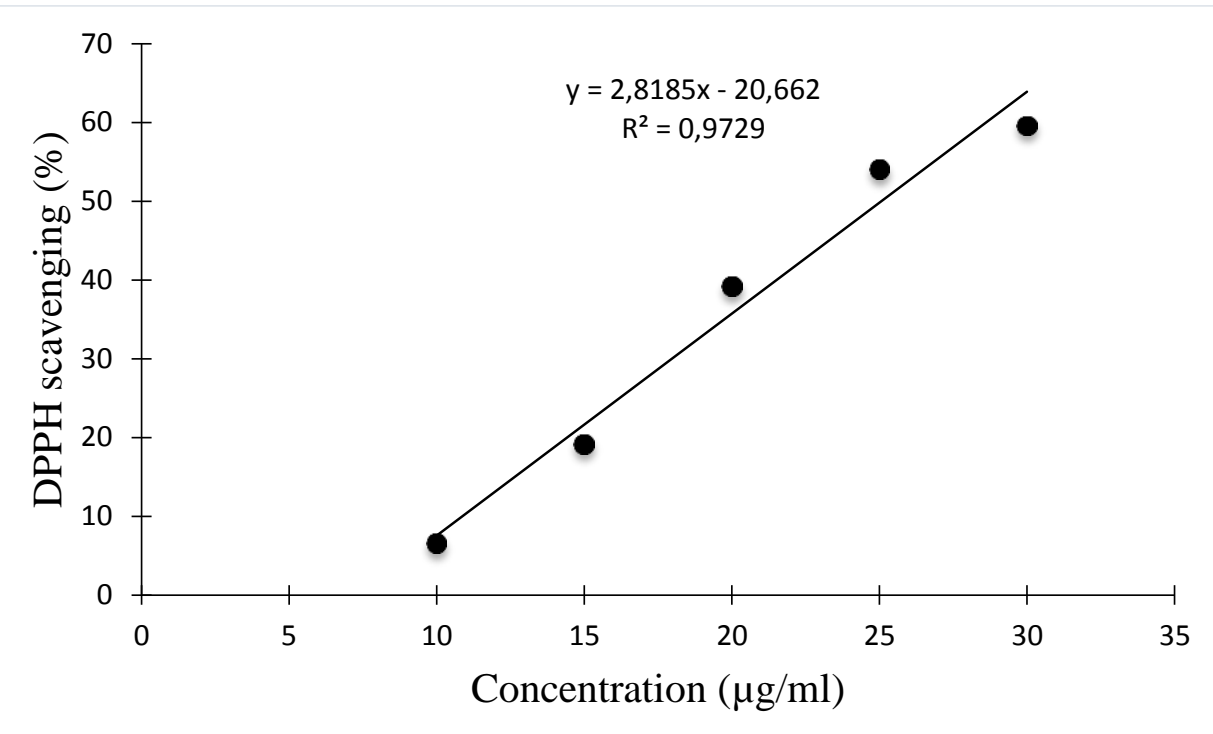

Figure 3. The DPPH free radical scavenging activity (\%) of quercetin 


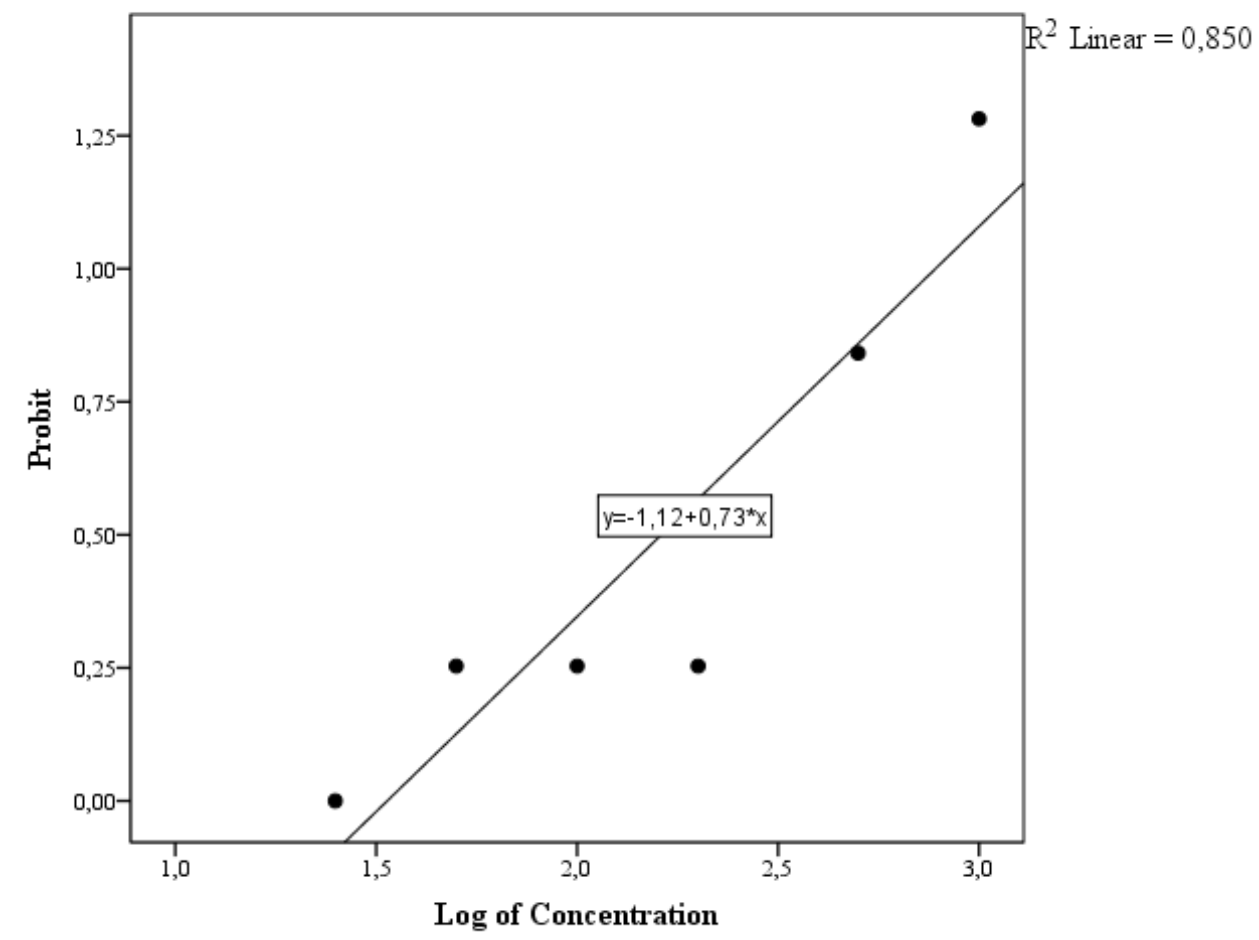

Figure 4. Relationship of $\log$ concentration of $96 \%$ ethanol extract of $C$. gynandra herb and the mortality of $A$. salina larvae 